«Системні технології» 2 (127) 2020 «System technologies»

DOI 10.34185/1562-9945-2-127-2020-09

УДК 629.78.533.6.013:621.45

А.Д. Игнатьев, Г.А. Стрельников, Е.Л. Токарева

\title{
МОДЕЛИРОВАНИЕ ИНТЕРЦЕПТОРНОГО РЕГУЛИРОВАНИЯ НАПРАВЛЕНИЯ ВЕКТОРА ТЯГИ РАКЕТНОГО ДВИГАТЕЛЯ
}

Аннотация. Актуальность темы состоит в необходимости разработки системы комбинированного управления вектора тяги ракетного двигателя с использованием твердых препятствий (интерцепторов) при одновременной инжекции через них отработанного генераторного газа или жидких компонентов ракетных топлив Цель работы: моделирование и численное исследование интерцепторного регулирования направления вектора тяги, выделение наиболее эффективного способа регулирования

Разработана модель газодинамического способа управления направлением вектора тяги, основанного на выдвижении в сверхзвуковой поток продуктов сгорания ракетного топлива твердого препятствия (интерцептора). Интерцептор выдвигается в сопло двигательной установки, в средней его части ближе к критическому сечению. Проведено численное моделирование и визуализация течения в сопле двигателя при выдвижении цельного интерцептора и интерцептора с отверстием, через который в пограничный слой вдувается газ навстречу потоку продуктов сгорания. Путем сравнения создаваемых элементарных боковых усилий показана возможность повышения эффективности управления направлением вектора тяги с помощью выдвижения интерцептора с одновременным вдувом газа.

Ключевые слова: управление вектором тяги, комбинированная система, интерцептор, вдув газа, моделирование, визуализация течения.

Введение. Газодинамическое регулирование направления вектора тяги ракетного двигателя основано на искусственном возмущении сверхзвукового потока продуктов сгорания в сопле двигательной установки. Возмущение генерируется вдувом отработанного газа турбонасосного агрегата двигателя, впрыском компонентов ракетного топлива или выдвижением твердого препятствия (интерцептора). Перспективной является интерцепторная система регулирования, основанная на выдвижении в сверхзвуковой поток в средней части сопла (ближе к критиче-

(C) Игнатьев А.Д., Стрельников Г.А., Токарева Е.Л., 2020 
«Системні технології» 2 (127) 2020 «System technologies»

скому сечению) твердых интерцепторов (круглых или плоских) относительно небольших размеров, при этом возможно использовать интерцепторы с одновременной инжекцией через них отработанного генераторного газа или жидких компонентов ракетных топлив. Этим защищается интерцептор от воздействия высокотемпературного, эрозионного сверхзвукового потока и создаются дополнительные легкорегулируемые по величине боковые усилия, а также снижаются размеры интерцепторов и уменьшается расход рабочего тела. На активном участке полета основную часть управляющего усилия создает интерцептор, а на повышенных режимах импульсное увеличение боковых сил обеспечивается форсированной инжекцией. Выбор оптимальных схем, рабочих тел и параметров интерцепторной системы впрыска остается актуальной задачей.

Постановка проблемы. Разработка комбинированной системы управления направлением вектором тяги [1-3], которая включает различные по принципу функционирования исполнительные органы, придала новый импульс исследованию газодинамических способов регулирования направлением вектора тяги ракетного двигателя [4-5]. Интерцепторная система регулирования в составе комбинированной системы управления позволяет повысить ее эффективность, в частности, решает проблему массовой ассиметрии, возникающей при работе космической ступени ракет [6]. Большим преимуществом такой системы является ее адаптируемость к существующим образцам ракетной техники.

Анализ последних исследований и публикаций. Интерцепторный способ регулирования направления вектора тяги до настоящего времени остается малоисследованным. Проведенные эксперименты позволили установить обобщенные эмпирические зависимости и получить картину течения возмущенного сверхзвукового потока [7]. Полученная картина возмущенного течения при выдвижении интерцепторов с отверстиями различного диаметра со вдувом газа показана на рисунке 1.

Выдвигаемый в сверхзвуковой поток интерцептор создает преграду набегающему потоку, при взаимодействии с которой генерируется скачок уплотнения и часть набегающего потока отклоняется от своего 


\section{«Системні технології» 2 (127) 2020 «System technologies»}

невозмущенного течения. При этом происходит отклонение вектора тяги от своего первоначального направления.
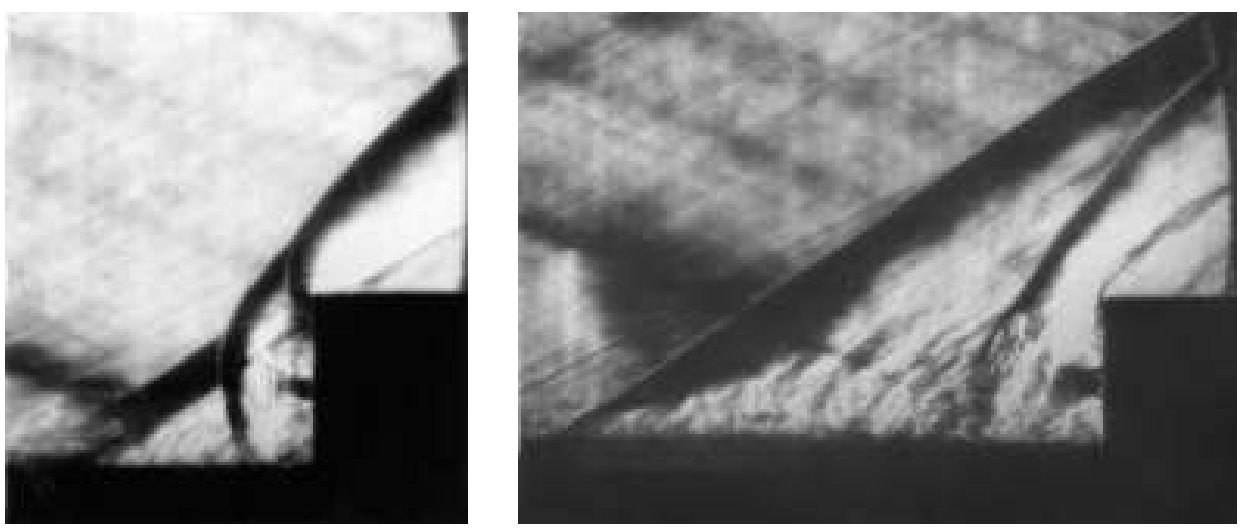

Рисунок 1 - Схема течения возмущенного сверхзвукового потока по результатам экспериментов

В публикациях [6, 7] показана эффективность интерцепторного способа регулирования при решении современных задач. Для космической ступени ракет крупные интерцепторы способны парировать последствия от массовой ассимметрии, возникающей при выводе полезного груза и сборе космического мусора.

Развитие технических средств позволяют провести достоверное и наглядное сравнение различных вариантов интерцепторного способа регулирования направления вектора тяги ракетных двигателей.

Цель работы - моделирование и численное исследование интерцепторного регулирования направления вектора тяги, анализ полученных результатов, выделение наиболее эффективного способа регулирования.

Основная часть. Моделирование интерцепторного способа регулирования направлением вектора тяги ракетного двигателя основывается на решении осредненных по Рейнольдсу уравнений Навье-Стокса (Reynolds Averaged Navier-Stokes) с помощью программного комплекса ANSYS FLUENT. Используется широко распространенная в аэрокосмиче-

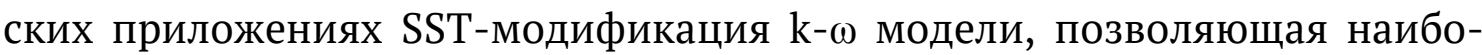
лее аккуратно предсказывать отрыв и хорошо работающая для пристенных отрывных течений. 
«Системні технології» 2 (127) 2020 «System technologies»

На рисунке 2 представлены результаты расчета распределения вектора полной скорости невозмущенного потока в сопле двигателя. Как видно из представленного рисунка, ускорение потока происходит без возникновения положительных градиентов давления.

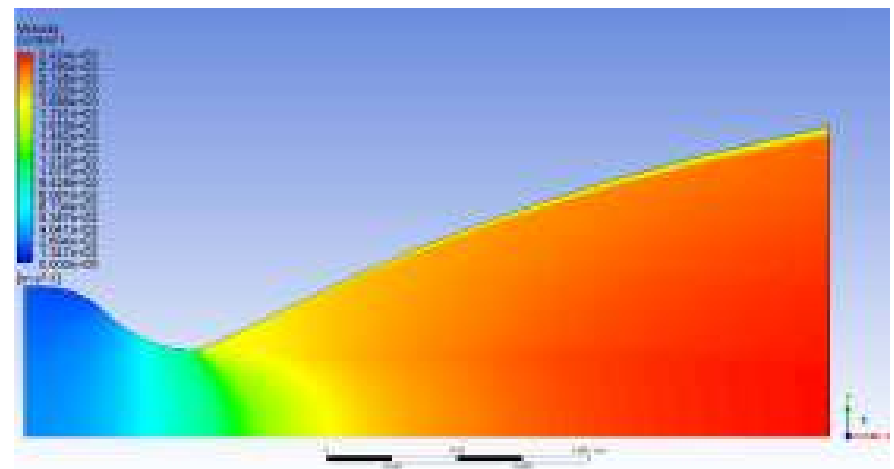

Рисунок 2 - Распределение вектора скорости невозмущенного потока

Интерцептор выдвигается в сопло двигательной установки, в средней его части ближе к критическому сечению. Размеры модели и расположение отверстия показаны на рисунке 3. На этом же рисунки представлены результаты расчета распределения вектора полной скорости потока сопла при выдвижении цельного интерцептора.

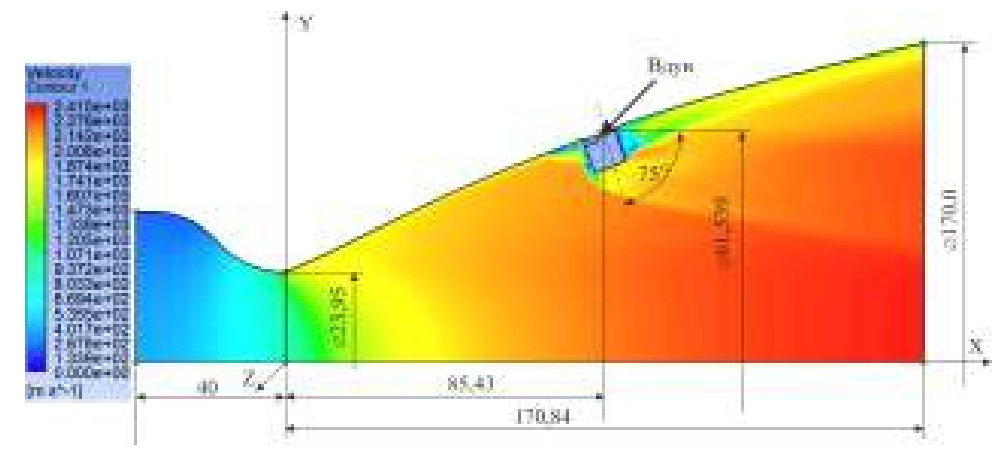

Рисунок 3 - Распределение вектора скорости потока, возмущенного выдвижение цельного интерцептора

На рисунках 4, 5 представлены результаты расчета распределения вектора полной скорости потока сопла при выдвижении интерцептора со вдувом для случаев, когда газ вдувается под давлением 10 атм и 15 атм, соответственно. Вдув газа через интерцептор и давление вдува значительно влияет на картину течения в сверхзвуковой области. Передняя отрывная зона резко возрастает, область возмущенного течения увели- 
«Системні технології» 2 (127) 2020 «System technologies»

чивается, возрастает неравномерность поля возмущенного давления на стенке сопла.

Смоделированная картина течения в сопле при взаимодействии основного потока с интерцептором показана на рисунке 6.

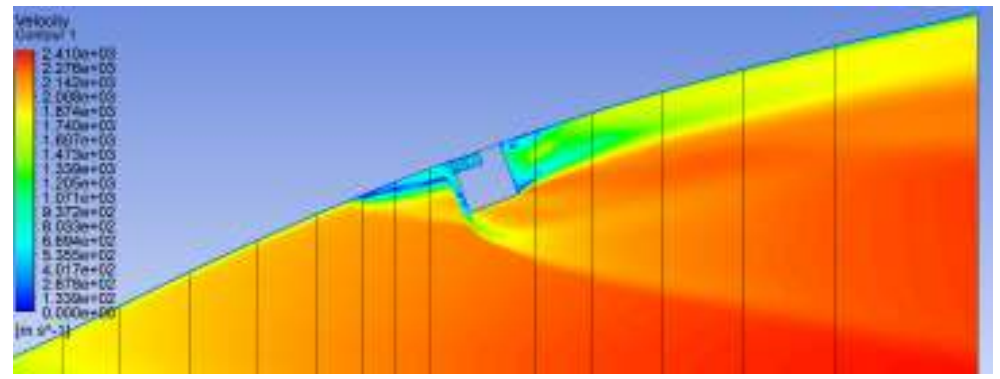

Рисунок 4 - Распределение вектора скорости потока, возмущенного выдвижение интерцептора со вдувом под давлением 10 атм

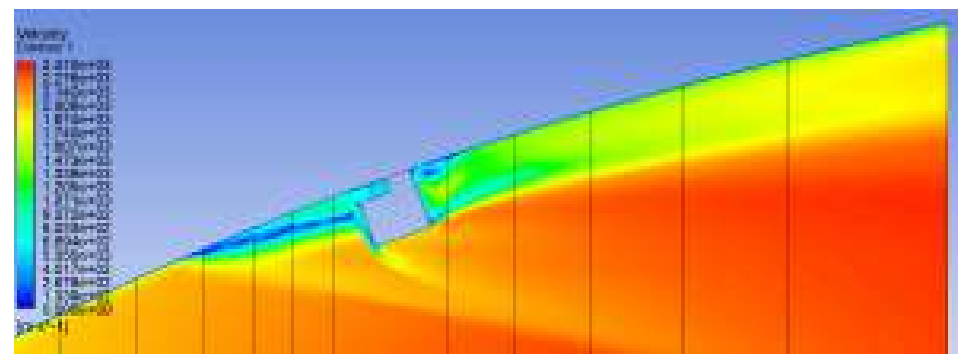

Рисунок 5 - Распределение вектора скорости потока, возмущенного выдвижение интерцептора со вдувом под давлением 15 атм

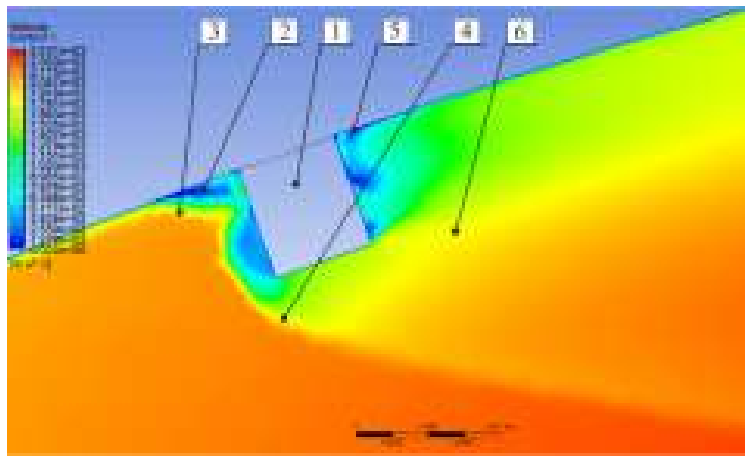

1 - интерцептор; 2 - передняя отрывная зона; 3, 6 - косой скачок уплотнения; 4 - криволинейная ударная волна; 5 - донная область

Рисунок 6 - Картина течения в сопле при взаимодействии основного потока с интерцептором

Установлено, что картина течения, полученная моделированием, соответствует картине течения, полученной при проведении экспери- 
«Системні технології» 2 (127) 2020 «System technologies»

ментов (рис. 1). Интерцептор 1 создает препятствие в виде ступеньки. Перед препятствием поток тормозится, происходит отрыв пограничного слоя с образованием трёхмерной отрывной зоны конусообразной формы 2, у вершины которой берёт начало косой скачок уплотнения 3, сливающийся ниже по основному потоку с криволинейной ударной волной 4. За интерцептором возникает донная область 5, а в месте присоединения струи к стенке возникает косой скачок уплотнения 6.

На рисунке 7 приведены графики, по которым можно сравнить результаты расчета давления вдоль стенки сопла при различных вариантах возмущения потока выдвижением интерцептора.

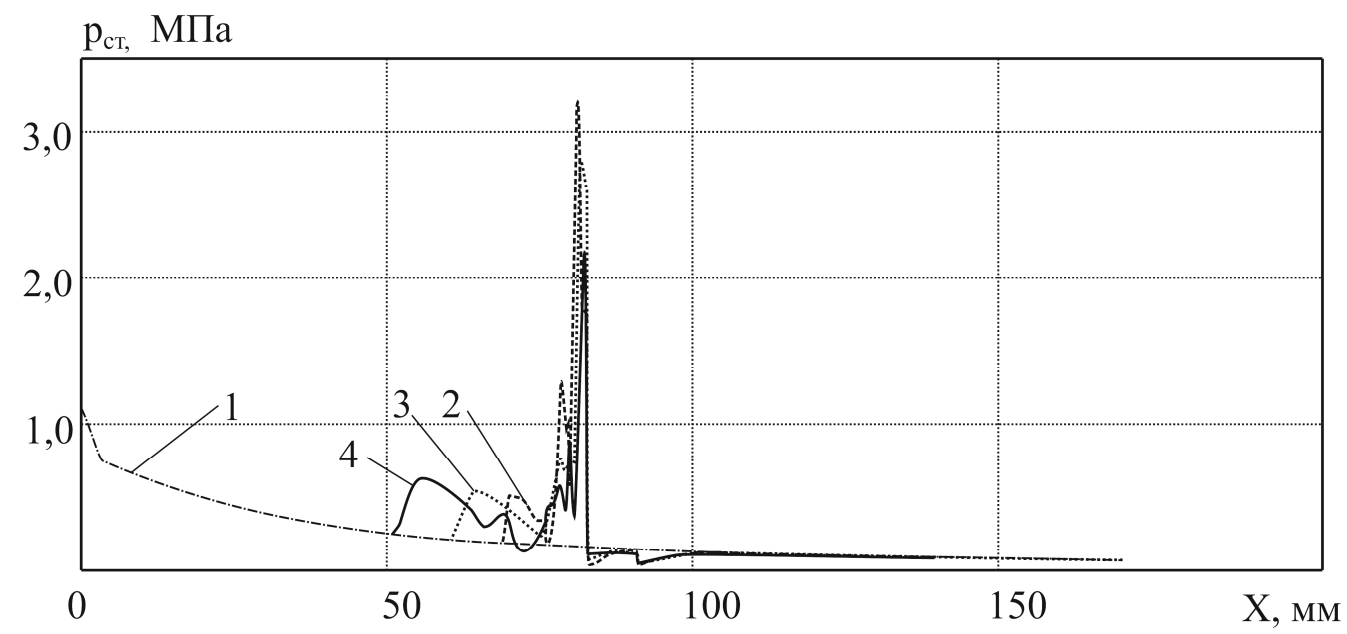

Рисунок 7 - Давление вдоль стенки сопла при различных вариантах организации интерцепторного регулирования

Кривая 1 соответствует невозмущенному потоку, кривая 2 - возмущению интерцептором со вдувом под давлением 15 атм., кривая 3 возмущению интерцептором со вдувом под давлением 10 атм, кривая 4 возмущению цельным интерцептором

Рисунок 7 иллюстрируют тот факт, что организация вдува повышает давление за скачком уплотнения, тем самым увеличивая отклонение потока и создаваемое боковое усилие. Увеличение давления вдува повышает эффективность регулирования.

Вывод. Выполнены моделирование и численные исследования невозмущенного и возмущенного (цельным интерцептором на стенке сопла и интерцептором со вдувом) сверхзвукового потока в сопле ракет122 
«Системні технології» 2 (127) 2020 «System technologies»

ного двигателя. Получены новые результаты по картинам возмущенного течения и эффективности управления сверхзвуковым потоком при интерцепторном регулировании. Показана возможность увеличения эффективности возмущения потока организацией вдува газа через интерцептор в пограничный слой навстречу набегающему сверхзвуковому потоку.

\section{ЛИТЕРАТУРА / ЛІТЕРАТУРА}

1. The new concept of thrust vector control for rocket engine / N.D. Kovalenko, Ю. Д. Sheptun, Т.A. Kovalenko, G.A. Strelnikov // Системні технології. - 2016. - № 6 (107). - С. 120-127.

2. Игнатьев А. Д. О модификациях перспективной системы управления вектора тяги двигателя третьей ступени ракеты-носителя типа «Циклон3» / А. Д. Игнатьев, Н. П. Сироткина, Н. Д. Коваленко // Техническая механика. - 2016. - № 4. - С. 14 - 23.

3. Стрельников Г. А. Управление газовыми потоками в ракетных двигателях ракет / Г.А. Стрельников, А.Д. Игнатьев, Н.С. Прядко, Е.Л. Токарева, Н. П. Сироткина // Техническая механика. - 2018. - № 3. - С. 59 - 68.

4. Стрельников Г. А. К разработке структурной схемы бифункциональной системы управления вектором тяги ракетного двигателя / Г. А. Стрельников, Е. Л. Токарева, Н. С. Прядко, А. Д. Игнатьев // Техническая механика. - 2018. - № 4. - С. 57 - 67.

5. Tokareva E.V., Ternova E.V., Pryadko N.S., Strelnikov G.A. BTVCS functional circuit on one control channel of the mid-flight space rocket stage engine // Системные технологии № 6 (119). - 2018. - С. 89 - 93.

6. Коваленко Т. А. Система управления вектором тяги жидкостного ракетного двигателя космической ступени ракеты-носителя при возникновении массовой асимметрии / Т.А. Коваленко, Ю.Д. Шептун, Н.П. Сироткина // Вестник Днепропетровского университета. Ракетно-космическая техника. - 2016. - Т. 24, № 4. - С. 33 - 44.

7. Коваленко Н. Д. Ракетный двигатель как исполнительный орган системы управления полетом ракет / Н. Д. Коваленко. - Днепропетровск : Институт технической механики НАН и НКА Украины, 2004. - 412 с.

\section{REFERENCES}

1. The new concept of thrust vector control for rocket engine / N.D. Kovalenko, Ю. Д. Sheptun, T.A. Kovalenko, G.A. Strelnikov // Системні технології. - 2016. - № 6 (107). - С. 120-127. 


\section{«Системні технології» 2 (127) 2020 «System technologies»}

2. Ihnatyev O.D. About modifications of a promising thrust vector control system for the engine of the third stage of the Cyclone-3 launch vehicle /O.D. Ihnatyev, N.P. Syrotkina, N.D. Kovalenko//Tech.mech.-2016.-№ 4.-P.14 -23. 3. Strelnikov G.O. Gas flow control in rocket engines / G.O. Strelnikov, O.D. Ihnatyev, N.S. Pryadko, O.L. Tokareva, N.P. Syrotkina // Tech. mech. - 2018. № 3. - P. 59 - 68 .

4. Strelnikov G.O. To the block diagram development of a bifunctional thrust vector control system of rocket engine / G.O. Strelnikov, O.L. Tokareva, N.S. Pryadko, O.D. Ihnatyev // Tech. mech. - 2018. - № 4. - P. 57 - 67.

5. Tokareva E.V. BTVCS functional circuit on one control channel of the midflight space rocket stage engine / Tokareva E.V., Ternova E.V., Pryadko N.S., Strelnikov G.A. // System technologies № 6 (119). - 2018. - P. 89 - 93.

6. Kovalenko N.D. Thrust vector control system for a liquid-propellant rocket engine of a launch vehicle space stage in the event of mass asymmetry / N.D. Kovalenko, U. D. Sheptun, Syrotkina N.P. // Bulletin of the Dnepropetrovsk University. Space rocket technology. -- 2016. - Vol. 24, № 4. - P. 33 - 44.

7. Kovalenko N.D Rocket engine as an executive body of a missile flight control system/N.D. Kovalenko // Dnepropetrovsk.: ITM NASU and NSAU, 2004.- 412p.

Received 13.02.2020. Accepted 14.02.2020.

Моделювання інтерцепторного регулювання напряму вектора тяги ракетного двигуна

Система комбінованого керування вектора тяги ракетного двигуна з використанням твердих перешкод (інтерцепторів) при одночасній інжекції через них відпрацьованого генераторного газу або рідких компонентів ракетного палива $\epsilon$ перспективною. Для космічної ступені ракет великі інтерцептори здатні парирувати обурення від асиметрії мас, яка виникає при виведенні корисного вантажу і зборі космічного сміття.

Розроблено модель газодинамічного способу управління напрямком вектора тяги, заснованого на висунення в надзвуковий потік продуктів згорання ракетного палива інтерцепторів. Інтерцептор висувається в сопло двигунної установки, в середній його частини ближче до критичного перетину. Проведено чисельне моделювання та візуалізація течії в соплі двигуна при висуненні цільного інтерцептора і інтерцептора 3 отвором, через який в при шар вдувається газ назустріч потоку продуктів згоряння.

Шляхом порівняння створюваних елементарних бічних зусиль показана можливість підвищення ефективності керування напрямком вектора тяги за допомогою висунення інтерцептору зі вдувом газу.

Interceptor regulation modeling of the thrust vector direction of a rocket engine

The topic relevance is the need to develop a combined system of the thrust vector control of a rocket engine using solid obstacles (interceptors) with simultaneously injecting exhaust gas or liquid components of rocket fuels through them. 
«Системні технології» 2 (127) 2020 «System technologies»

Analysis of recent research and publications. The interceptor method of the thrust vector direction control hasn't so far been well explored. The experiments conducted earlier made it possible to establish generalized empirical dependences and to obtain a picture of a perturbed supersonic flow.

The purpose of the work is modeling and numerical study of the interceptor regulation of the thrust vector direction, the selection of the most effective way of regulation.

Modeling is based on solving the Reynolds-averaged Navier-Stokes equations using the ANSYS FLUENT software package (SST-modification of the $k$ - $\omega$ model).

A model of a gas-dynamic method for control the thrust vector direction based on the extension of a solid obstacle (interceptor) into the supersonic flow of combustion rocket fuel products is developed. New results have been obtained on the patterns of perturbed flow and the efficiency of supersonic flow control during interceptor control. The results were verified by previous experimental studies. Based on the results of comparing the generated elementary lateral forces, the possibility of increasing the control efficiency of the thrust vector direction by extending the interceptor with simultaneous gas injection is shown.

A numerical simulation of the supersonic perturbed flow in the rocket engine nozzle is carried out, based on the solution of the Navier-Stokes equations. According to the results, the flow in the engine nozzle was visualized when the whole interceptor and the interceptor with an opened hole were pulled out, through the last gas was blown into the boundary layer towards the flow of combustion products. The data of previous experimental studies are confirmed. The developed model can serve as the basis for conducting numerical experiments of the interceptor method for regulating the thrust vector direction. The obtained results can be used to simplify and reduce the terms of design development of controls when creating new and modernizing standard models of rocket technology.

Игнатьев Александр Дмитриевич - к.т.н.,старший научный сотрудник Института технической механіки НАН Укратины и ГКА Украины.

Стрельников Геннадий Афанасьевич - д.т.н., и.о. заведующий отделом Института технической механіки НАН Украины и ГКА Украины.

Токарева Елена Леонидовна - младший научный сотрудник Института технической механіки НАН Украины и ГКА Украины

Ігнатьєв Олександр Дмитрович - к.т.н., старший науковий співробітник Інституту технічної механіки НАН України і ДКА України.

Стрельников Геннадій Опанасович - д.т.н., в.о. завідувача відділу Інституту технічної механіки НАН України і ДКА УкраїниТокарева Олена Леонідівна - молодший науковий співробітник Інституту технічної механіки НАН України і ДКА України.

Ihnatyev Oleksandr - Ph.D, Senior Researcher, Institute of Technical Mechanics of the National Academy of Sciences of Ukraine and State Space Agency of Ukraine.

Strelnikov Gennadiy - Doctor of Technical Sciences, Institute of Technical Mechanics of the National Academy of Sciences of Ukraine and State Space Agency of Ukraine.

Tokareva Olena- Junior Researcher, Institute of Technical Mechanics of the National Academy of Sciences of Ukraine and State Space Agency of Ukraine. 